\title{
A Reseach on Fundamental Access of Selected Automobile Companies in India
}

\author{
Akansha Nagpal, Himanshu Chandok, Meghna Chhabra
}

\begin{abstract}
Today, the most important strength of volatile financial market is information. Fixed income securities are for more risk-averse investors where as young people are more interested in equity shares as they like to take more risk in lieu of more return. Prices of these securities move according to the information available in the financial market. Investors are always confused regarding Where to invest, When to invest and How much to invest. Fundamental analysis is a method which helps an investor in knowing "What the price should be" or "What is the real value of a share". It is based on the foundation that in the long run, the true value of a share will be equal to its intrinsic value i.e. present value of all the future cash inflows from the share in the form of dividends as valuation of equity shares are based on the assumption of going concern concept of business. Fundamental analysis involves analyzing the economy wide factors (e.g. GDP growth rate, employment etc), industry wide factors (e.g. competition, nature of product etc) and companywide factors (e.g. financial statements, corporate governance, management efficiency etc). It is also quoted by John Forman, "Fundamental analysis is very powerful in terms of determining long-term direction, but lacks short-term applicability". The automobile industry is considered to be one of the key drivers of economic growth as it involves huge investment at the same time large profit to automobile companies. On the basis of past performance, it is analyzed that the demand outlook of automobile industry will continue to grow in 2018-19 due to healthy sales momentum in rural areas as well. This built confidence among the investors to invest in automobile industry which is highly rewarding at the same time it is highly risky in long run.
\end{abstract}

Keywords: Fundamental analysis, automobile industry, intrinsic value.

\section{INTRODUCTION}

Fundamental analysis is the cornerstone in investment. In fact, many say that without performing fundamental analysis you aren't actually investing. There are number of investment strategies that are different from each other, yet every strategy involves use of fundamental analysis. This is why, every investor is highly suggested to learn in-depth about fundamental analysis. After learning the concept of fundamental analysis, investor would be able to understand how fundamental analysis helps in boosting the success of investing in any security regardless of the approach of buying and selling stocks. Fundamental analysis is a method of analyzing and evaluating securities of different companies in an attempt to assess their intrinsic value.
Intrinsic value is the actual value of a company's stock which is determined by performing economic, industry and company analysis, known as E-I-C framework. In this way, in order to forecast future stock prices, fundamental analysis combines economic, industry and company analysis to arrive at its fair value which is nothing but its intrinsic value. In course of attempting fundamental analysis, investors generally study the aspects of macro economy first i.e., economic trend and its overall health, industry's trend and its growth prospects, forces of demand and supply of the products etc. After that, they examine the aspects of micro economic i.e., study of company's financial statements, competitor's performance, company's management, business model etc. One important aspect of fundamental analysis includes delving into company's financial statements. This basically comes under quantitative analysis which involves looking at assets, liabilities, revenue, expenses and all other financial aspects of company's financial statement. Also there are certain factors like business model, competitive advantage, operational efficiency, management etc which must be taken into consideration during qualitative analysis. These all are intangible, difficult-to-measure aspects of a company. As with all these analysis, the main purpose is to develop a calculated forecast to predict movement of future stock price and profit generated from it. Fundamental analysts look at this information to make judgment on whether to invest in the company on the basis of company's future performance.

In India, the automobile industry has become the 4th largest in the world with an increase in sales by 9.5 per cent year-on-year to approximately 4.02 million units (not including two wheelers) in 2017 and was at 7 th position in the ranking of largest manufacturer in the market of commercial vehicles during 2017 . This gradually increases the scope of investing in the automobile industry. According to report by "India Brand Equity Foundation", production of Domestic automobile is increased by approximately 7.08 per cent in CAGR between Financial years 2013-18 with around 29.07 million vehicles being manufactured during FY18. With such increase in production, the sale of domestic automobile is also increased by 7.01 per cent in CAGR between financial years 2013-18 with around 24.97 million vehicles being sold in FY18.

Revised Manuscript Received on September 10, 2019.

Akansha Nagpal, Associate Professor, Manav Rachna International Institute of Research and Studies, New Delhi, India.

Himanshu Chandok, Associate Professor, Manav Rachna International Institute of Research and Studies, New Delhi, India.

Dr. Meghna Chhabra, Associate Professor, Manav Rachna International Institute of Research and Studies, New Delhi, India.

(email: meghnachhabra28@gmail.com) 


\section{LITERATURE REVIEW}

- Jenni et al. (2008) in their paper constructed an equity valuation model by integrating both the fundamental and technical analysis. In the paper, the authors emphasized that both fundamental and technical analysis are complimentary and not substitutes of the other and are poles apart. The study shows that combining both the fundamental and technical can help the investor in achieving their investment goals and hence both the models do not operate in complete isolation rather possess superior explanatory power

- Chauhan (2014), performed fundamental analysis with reference to selected automobile companies and concluded that though there is a decline in the GDP growth rate of India (2008-09 to 2012-2013), the automobile sector still managed to shine. She concluded the results on the basis of SWOT analysis and ratio analysis of two automobile companies, i.e., Maruti Suzuki India and Tata Motors Ltd and found out that the performance of Maruti Suzuki is comparatively better than that of Tata Motors in terms of its Return on Investment, Current ratio and Earnings per share. Also, she mentioned that fundamental analysis is for those investors who have a long-term perspective and want to invest huge amount. Following this approach, our paper has taken care of the needs of long term investors and gives recommendations on whether a security (of chosen sample companies) should be bought or sold depending upon its real or fair worth.

- Christie \& Isidore (2018) in their paper stated the pros and cons of fundamental and technical analysis. By doing fundamental analysis, an investor can predict in advance the price of a share before any change actually happens with the coming up of new information. Moreover, the authors explained the importance of doing economic and industry analysis in forecasting the growth opportunities for shares, and how fundamental analysis can meet the needs of long-term investors.

\section{OBJECTIVES OF THE STUDY}

- To study the growth and financial performance of automobile sector in India.

- To study the fundamental analysis of selected automobile companies in order to recommend for better investment decisions.

- To calculate the intrinsic value of the shares of selected automobile companies in order to forecast their real worth or value with the help of fundamental analysis.

\section{RESEARCH METHODOLOGY \& RESULTS}

The study is conducted mainly on the basis of secondary data collected from various sources such as internet, websites including money control, equity master, books, etc. Data analysis is done with the help of tools used in fundamental analysis for selected automobile companies. The scope of the study is limited to the selected automobile companies chosen for analysis. The selection of companies for the purpose of analysis is done on the basis of convenience sampling listed on NSE and BSE. As per the content of this research, E-I-C framework of automobile sector is to be performed. For the analysis part, all the selected five companies among the top most revenue generating and growing automobile companies will be taken into consideration one by one.

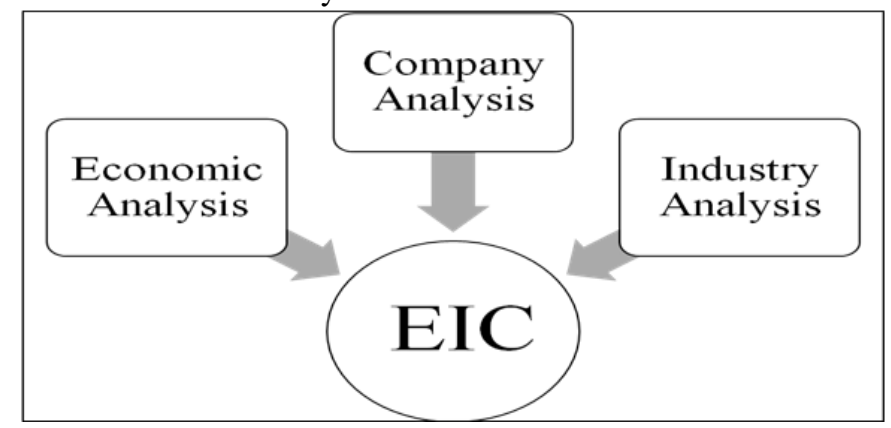

E-I-C FRAMEWORK:

I) Economic analysis:-

Primary step under EIC framework is to study the economy to determine the overall condition of the stock market. Economic analysis is performed to know the favorability of economy in reference with the stock market by identifying its current performance using macro economic factors like GDP, Inflation rate, Current account deficit, Unemployment rate.

Table I. Summarized macroeconomic factors for India (2013-18)

\begin{tabular}{|l|l|l|l|l|}
\hline \multicolumn{5}{|c|}{ Table I. Summarized macroeconomic factors for India (2013-18) } \\
\hline Year/factors & $\begin{array}{l}\text { GDP Growth } \\
\text { Rate (\%) }\end{array}$ & Inflation (\%) & $\begin{array}{l}\text { Unemployment } \\
\text { Rate (\%) }\end{array}$ & $\begin{array}{l}\text { Current Account } \\
\text { Deficit (\%) }\end{array}$ \\
\hline $2013-14$ & 6.6 & 5.8 & 3.41 & 1.7 \\
\hline $2014-15$ & 7.2 & 4.9 & 3.49 & 1.3 \\
\hline $2015-16$ & 7.9 & 4.5 & 3.51 & 1.1 \\
\hline $2016-17$ & 8.2 & 3.6 & 3.52 & 0.6 \\
\hline $2017-18$ & 7.2 & 3.3 & 6.1 & 1.9 \\
\hline
\end{tabular}

1. Gross domestic product(GDP) growth rate: The total production of goods and services in an economy is cumulatively known as aggregate output which generates income for that economy. Hence aggregate output is closely associated with economy's aggregate income. The United States first uses gross domestic product (GDP) as a term to state aggregate output. Therefore GDP is a monetary concept to measure the value of goods and services of an economy in a specific period of time, often annually. So from this analysis, it is clear that though GDP growth rate has shown ups and downs over the last 5 years (from 2013 14 to 2017-18) but the overall performance of GDP growth rate has reflected a positive trend to the economy which is a good indicator for the investor to take investment decision. 


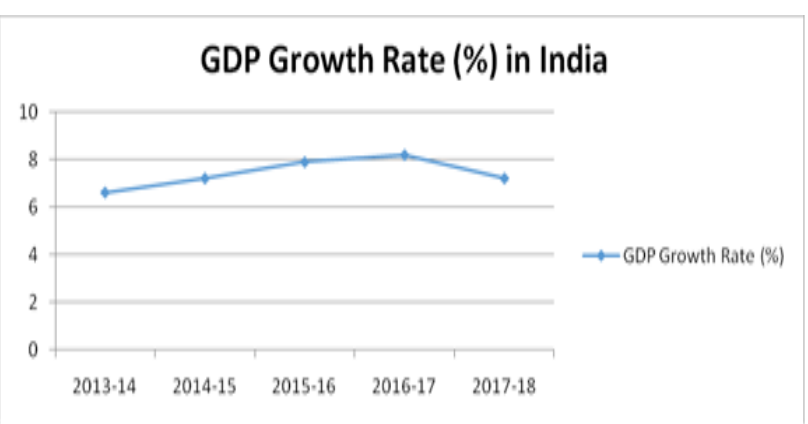

Fig. II GDP growth rate in India, Source: economic times

2. Inflation rate: The inflation rate refers to the rate of continuously rise in the price level. Inflation is defined as a situation where the price of goods and services in an economy tend to rise due to which consumers are supposed to pay more for the same product now. This obviously decreases the purchasing power of the people as they have less money in hand. So this is a negative indicator for the investors. As per the graph given below, it is clear that the inflation rate over the last five years i.e., from 2013-14 to 2017-18 has decreased from $5.8 \%$ to $3.3 \%$. If you see the given graph, you will find a continuous decrease in inflation rate from FY 2013-14 to FY 2017-18 reflecting the overall performance of the trend to be good.

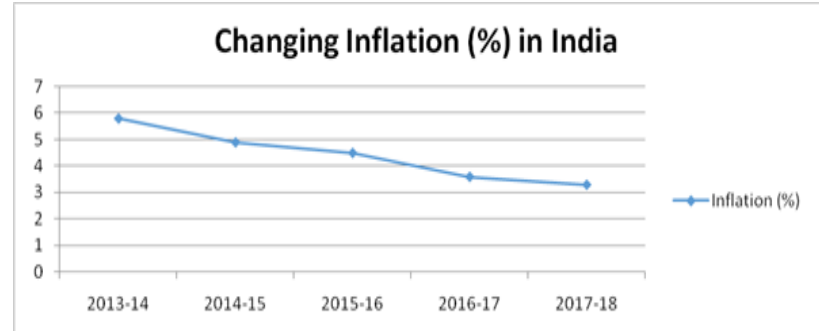

Fig. III Changing Inflation rate in India- Source: statista.com

3. Unemployment rate: The unemployment rate is an indicator of unemployment prevailing in an economy. It is calculated by dividing the total number of individuals who unemployed are by totaling number of individuals in labor force. As per the table, economy has shown a continuous increase in unemployment rate from $3.41 \%$ in $2013-14$ to $3.52 \%$ in $2016-17$ by small percentage but then due to some economic fluctuations it took a sudden increase of $2.58 \%$ in 2017-18 and become $6.1 \%$ indicating a negative sign to the investors.

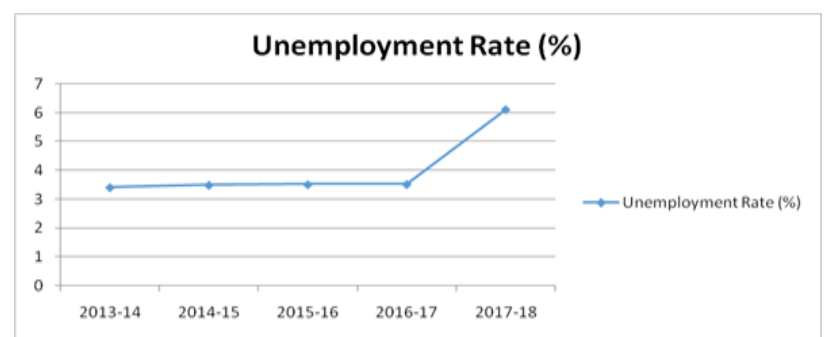

Fig IV. Unemployment rate in India (2013-2018) Source: CEIC Data

4. Current account deficit: The current account deficit indicates shortfall in international trade of a country where the value of goods or services being imported exceeds the value of the goods or services being exported. The current account is a component of balance of payment (BOP) which includes all transactions related to international trade. According to the graph given below, the trend line of CAD (current account deficit) is seemed to be decreased gradually from $1.7 \%$ in $2013-14$ to $0.6 \%$ in 2016-17. This is absolutely a good indicator for the economy as net inflow is gradually decreasing. But in 2017-18 the CAD has increased

\section{Current Account Deficit (\%)}

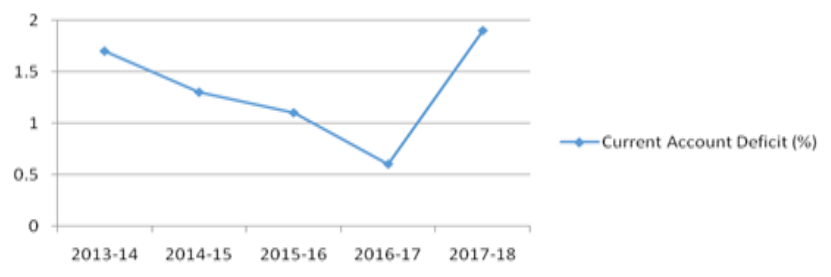

to $1.9 \%$ due to higher trade deficit.

Fig V. Current account deficit in India (2013-2018), Source: website of Reserve Bank of India

II) Industry analysis:- Industry analysis is a part of EIC framework which is performed after doing economy analysis. It constitutes one of the three pillars of EIC framework which is being performed under fundamental analysis.Industry analysis helps in understanding some of the major aspects of a specific industry to help investors in making investment decisions.

Porter's 5 forces model: Michael Porter designed 5 forces model to determine the structure of any industry. He had come up with number of vital framework but the most renowned one among managers making strategic decisions is the "porter's 5 forces model". Industry depends upon the following 5 factors:

- Threat of new entrants

- Threat of substitute

- $\quad$ Bargaining power of buyers

- $\quad$ Bargaining power of suppliers

- $\quad$ Rivalry among existing firms

Now discussing every factor in reference with our research paper:-

$>\quad$ Threat of new entrants:-

As per the report of IBEF (India Brand Equity Foundation), automobile export is expected to increase at a CAGR of 3.05\% during 2016-2026. Also several initiatives, taken by the government of India and major players in automobile industry, are expected to make India a leader of two wheeler and four wheeler vehicles in the world by 2020 . So these many opportunities provide firms with high returns and big profits due to which new entrants may get attracted towards automotive sector. The restrictions may be due to:

- $\quad$ Patents requirement and other rights

- Government policy

- Capital requirement

- $\quad$ Economies of scale, etc. 
$>\quad$ Threat of substitute:- Substitute product refers to the product which has the ability to satisfy the customers' demand by using different technology. A firm producing substitute of a product will give tough competition to the other firms in the market. Currently in automobile sector, one biggest threat of substitute for petroleum vehicles is came out to be of EV (electronic vehicles).

Bargaining power of suppliers:- Suppliers refer to the firms which are engaged in providing input to the industry. The bargaining power of suppliers in automobile industry is very low (weak) because all the suppliers are more or less same in terms of input availability and its price offering which decreases their power.

$>$ Bargaining power of buyers:- Buyers refer to the final consumers who will finally purchase the good for their consumption. Bargaining power of buyers mean potential of the buyers to decrease the price of the product/services charged by the firm. Different buyers are:

- Individual buyer (single vehicles for personal use)

- Government agencies and corporation (fleets of vehicle for commercial use)

The bargaining power of buyers is high because individual buyer in automobile market can easily switch to some other brand if he finds the current availing brand to be more expensive. Also government agencies and corporation are in position to bargain for lower price of vehicle.

Rivalry among existing firms:- Rivalry refers to the firms who are in competition for capturing market share in that particular industry. These firms possess a strong threat to profitability. If talking about the current rivalry, there are some companies like Toyota, Honda, Mahindra, Hyundai who are giving cut throat competition to each other.

1. Government policies and initiatives: Industry analysis also takes into consideration all those initiatives taken by Government of India for the development and growth of the industry. Recent initiatives taken by the Government are -

- The Indian government aims to make India as a global manufacturing centre and a Research and Development hub.

- Under NATRIP, the Indian Government planned to set up Research and Development centers which cost 388.5 US million dollars to make the industry operate with the global standard.

- The government of India also planned to set up incubation centre in coming years for assisting start-ups working in electric vehicles space.

- Some of the major initiatives taken by government of India are:

$\rightarrow \quad$ National Mission For Electric Mobility 2020

$\rightarrow \quad$ Automotive Mission Plan 2026

$\rightarrow \quad$ Make in India

$\rightarrow \quad$ Electric Vehicle (EV) Mission 2030

- Industry life cycle:

- Startup:- At this stage, customers are unfamiliar with the features and performance of a new product due to which its demand remains limited.

- Growth: - As the product starts gaining popularity among customers, it comes out from the startup stage and enters in the growth stage. Innovation, invention and improvement in product lead to continuous growth, leading to huge profit.

- Maturity: -Companies in the industry try to operate collectively to tackle with the industry competition and maintain profitability by adopting various strategies.

- Decline: -. Companies decide to focus on their most profitable product lines and stop the production of out trended product or services in order to survive in the industry. One last option at this stage, for those who have lost everything in their business and have no believe to survive, is divestment.

2. Industry SWOT analysis: - SWOT analysis is a marketing term which means a study undertaken by an organization or industry.

\section{Strength of automobile industry:}

$\rightarrow \quad$ Automobile industry has growth prospect in future as automobile provides people ease of living, working and traveling in a better way than ever before. Automobile is now no more a luxury product but a necessity which provide growth opportunity to the industry.

$\rightarrow$ Technology advancement: with the passage of time, automobile industry is coming up with new innovative features and technologies to stay in the race. A very recent example is of EV (electric vehicles).

$\rightarrow \quad$ Rising demand: Automobile is an industry where demand is continuously increasing because of its comfort and status. Rising demand led the sale of domestic automobile to increase by 7.01 per cent in CAGR between financial years 2013-18 with around 24.97 million vehicles being sold in FY18.

$>$ Weakness: weakness refers to the characteristics of an industry which plays a negative role and put the firm or industry at disadvantageous position.

\section{Weakness of automobile industry:}

$\rightarrow \quad$ Bargaining power of consumers: The bargaining power of buyers is high in automobile industry because individual buyer can easily switch to some other brand if he finds the current availing brand to be more expensive.

$\rightarrow \quad$ Entry barriers for new firms: New entrants are supposed to face certain restrictions which keep the threat of new entrants at lower level. These restrictions may be due to:

- Patents requirement and other rights

- Government policy

- Capital requirement

- $\quad$ Economies of scale, etc.

$\rightarrow \quad$ Government interference: The government of India levied certain regulations like excise duty, entry barriers of outside vehicles in the state, price volatility of fuel etc.

Opportunity: opportunity refers to the positive element in an industrial environment which can enhance its performance and provide competitive edge in the market. 


\section{Opportunity in automobile industry:}

$\rightarrow$ Introduction of EVs (Electronic Vehicle): Electronic Vehicle refers to the vehicle that works without using fuel. It works electronically to move on the roads without using fuel. This helps in protecting environment and saving fuel.

$\rightarrow \quad$ Government's expectation and initiatives: If talking about automotive industry, government has taken several initiatives with the expectation to make India a leader of two wheeler and four wheeler vehicles in the world by 2020 .

$\rightarrow \quad$ High prospect of rising demand: automotives are in a heavy demand because it becomes a status symbol for the customers. As per the data, the sale of domestic automobile has increased by 7.01 per cent in CAGR between financial years 2013-18 with around 24.97 million vehicles being sold in FY18.

$>$ Threats: It refers to the elements in organization's or industry's external environment which hinder its performance and possess challenges in the market to survive.

\section{Threats in automobile industry:}

$\rightarrow$ Intense competition: in automobile industry, competition is running at its peak. Increasing demand of vehicles and introduction of EVs has invited many companies to provide tough competition in the industry.

$\rightarrow \quad$ Mission Electric Vehicles: Electric vehicle though is a good opportunity for the companies brings with it certain challenges during its initial stage. These challenges are:

III) Company analysis: - Company analysis is a study to analysis the financial performance of a company or an industry so that its profitability can be checked before investing in that company. This analysis is undertaken to know the risk and return associated in purchasing share of that company.

IV) Management efficiency: - Company and its employees need good and efficient management to achieve overall company's goal. It is well said that a best business plan or model may get failed without having management.

1. Earning and financial performance: - Earning scale of automobile is also impressive as it has shown in the graph, the vehicle domestically sold in FY year 2013-14 was 18.42 million which has increased to 24.97 million in FY 2017-18. As the sale has increased, earning must also have increased by good amount along with increase in profit.

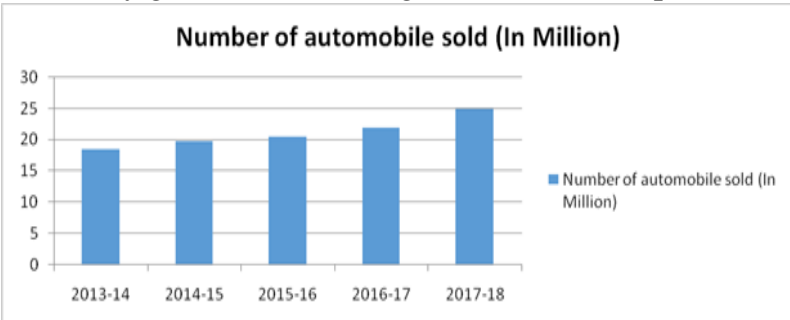

Fig VI. Automobiles sales figures in India (2013-2018) Source: India Brand Equity Foundation

2. Ratio analysis:- For the sake of simplicity in doing ratio analysis of automobile industry, five top most automobile companies which will represent industry as whole was selected. Financial data of selected companies is taken from 2013-14 to 2017-18.
1. Earnings Per Share: The earnings per share (EPS) is an indicator of the profitability of a company. It is calculated by dividing net income from number of common shares outstanding at the end.

\begin{tabular}{|l|l|l|l|l|l|}
\hline \multicolumn{7}{|c|}{ Table II. EPS of five companies (2013-2018) } \\
\hline Years & $\begin{array}{l}\text { Maruti } \\
\text { Suzuki }\end{array}$ & $\begin{array}{l}\text { Mahindra \& } \\
\text { Mahindra }\end{array}$ & Tata motors & Force Motor & SML Isuzu \\
\hline $2013-14$ & 94.44 & 61.02 & 43.51 & 59.08 & 12.02 \\
\hline $2014-15$ & 126.04 & 53.47 & 43.44 & 77.06 & 25.53 \\
\hline $2015-16$ & 181.98 & 51.60 & 34.25 & 136.29 & 35.35 \\
\hline $2016-17$ & 248.64 & 58.66 & 21.94 & 136.75 & 43.54 \\
\hline $2017-18$ & 260.88 & 35.04 & 26.46 & 111.72 & 5.87 \\
\hline \multicolumn{7}{|c|}{ Source: Money control } \\
\hline
\end{tabular}

Implication: - The implication of EPS is that it helps in knowing how much money a company is earning for all of its shareholders. According to the table, Maruti is the only company who has shown a continuous growth in EPS from 94.44 in FY 2013-14 to 260.88 in FY 2017-18. All other companies have shown fluctuation mostly in FY 2017-18.

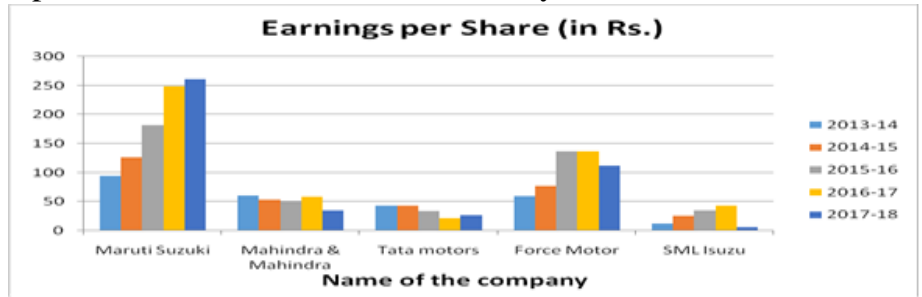

Fig VII. Graphical representation of EPS of five companies (2013-2018)

In the above graph, name of the companies representing industry as a whole is shown on $\mathrm{X}$ axis and EPS of all the companies from FY 2013-14 to FY 2017-18 is shown on Y axis. It helps in understanding the fluctuation and changing trend of EPS over the years. EPS of Maruti and force motor have increased over the five years indicating positive trend to the shareholders. Force motor and SML Isuzu have shown a fall in FY 2017-18. Mahindra \& Mahindra and Tata motor have shown decreasing trend in most of the years which is not a good indicator for the shareholders. Return on equity (ROE): It is an indicator of how effectively and efficiently company's management is using its equity to create profit. It is a measure of annual return of a company generated from the utilization of equity shareholder's amount. It is calculated by dividing net income (annually) form equity shareholder.

\begin{tabular}{|l|l|l|l|l|l|}
\hline \multicolumn{7}{|c|}{ Table III. ROE of five companies (2013-2018) } \\
\hline $\begin{array}{l}\text { Maruti } \\
\text { Years }\end{array}$ & $\begin{array}{l}\text { Mahindra \& } \\
\text { Suhindra }\end{array}$ & Tata motors & Force Motor & SML Isuzu \\
\hline $2013-14$ & 13.27 & 20.03 & 21.33 & 6.34 & 6.29 \\
\hline $2014-15$ & 15.65 & 12.14 & 24.86 & 7.70 & 12.19 \\
\hline $2015-16$ & 17.95 & 13.41 & 14.66 & 12.11 & 15.04 \\
\hline $2016-17$ & 20.25 & 12.43 & 12.83 & 10.79 & 15.60 \\
\hline $2017-18$ & 18.51 & 20.42 & 9.41 & 8.16 & 2.13 \\
\hline \multicolumn{7}{|c|}{ Source: Money control } \\
\hline
\end{tabular}

Blue Eyes Intelligence Engineering \& Sciences Publication 
Implication: - An increase in ROE tells that a company is able to generate good profit without requiring much amount of capital. Higher the ROE, more effective is the utilization of shareholder's capital. ROE of Maruti was $13.27 \%$ in FY 2013-14 which kept on rising till FY 2016-17 and became 20.25 but in final year it became $18.51 \%$. Similar happened in the case of SML Isuzu. All rest has shown ups and downs in their performance.

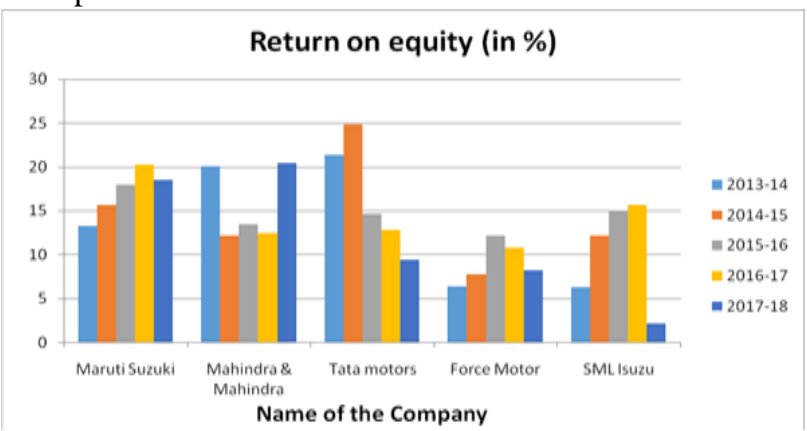

Fig VIII. Graphical representation of EPS of five companies (2013-2018)

This graph is the graphical representation of the data given in the table. Maruti, Force motor and Mahindra \& Mahindra have shown an overall increase in ROE ratio over the 5 years. ROE of Maruti Suzuki and SML Isuzu have continuously increased till FY 2016-17 showing positive trend to shareholder but then mark some disappointment by decreasing in the last year. Tata motor has performed worst by continuously falling showing decreasing trend and shaking the confidence of shareholders. ROE by reflects ups and down.

2. Price to earnings ratio $(\mathrm{P} / \mathrm{E}$ ratio): $\mathrm{P} / \mathrm{E}$ ratio is one of the most important ratios in company analysis. Many investors and analysts use this ratio to find out intrinsic value of companies. The price to earnings ratio is the ratio used for valuing a company. It takes into account the current market price in relation to its EPS.

\begin{tabular}{|l|l|l|l|l|l|l|}
\hline \multicolumn{7}{|c|}{ Table IV. Price to Earnings ratio of five companies (2013-2018) } \\
\hline Years & $\begin{array}{l}\text { Maruti } \\
\text { Suzuki }\end{array}$ & $\begin{array}{l}\text { Mahindra Earnings Ratio (in Rs.) } \\
\text { Mahindra }\end{array}$ & Tata motors & Force Motor & SML Isuzu \\
\hline $2013-14$ & 21.40 & 16.44 & 7.59 & 5.86 & 27.77 \\
\hline $2014-15$ & 30.11 & 22.48 & 9.28 & 18.22 & 45.71 \\
\hline $2015-16$ & 23.85 & 23.72 & 9.50 & 20.97 & 23.89 \\
\hline $2016-17$ & 24.80 & 20.66 & 19.95 & 32.87 & 29.65 \\
\hline $2017-18$ & 35.47 & 23.31 & 9.54 & 25.50 & 445.52 \\
\hline \multicolumn{7}{|c|}{ Source: Equity master } \\
\hline
\end{tabular}

Implication: - Implication of $\mathrm{P} / \mathrm{E}$ ratio is that a higher $\mathrm{P} / \mathrm{E}$ ratio means that the investors or shareholders are expecting higher growth in future. Every company has shown fluctuation in its $\mathrm{P} / \mathrm{E}$ ratio making investors confused regarding future growth prospect. The $\mathrm{P} / \mathrm{E}$ ratio of SML Isuzu has shown a high increase in 2017-18 and become 445.52.

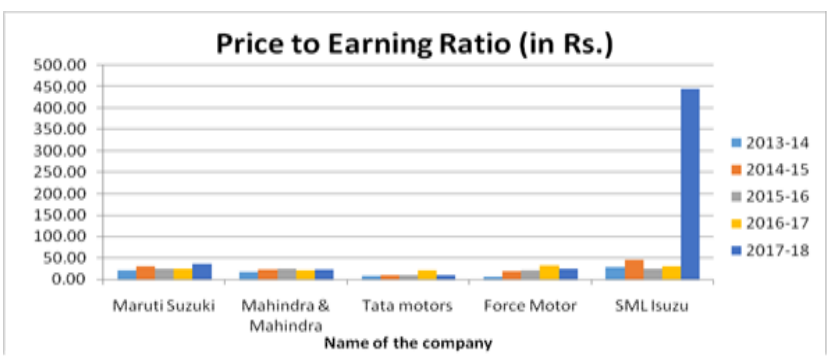

Fig IX. Graphical representation of Price to Earnings ratio of five companies (2013-2018)

Maruti Suzuki, Mahindra \& Mahindra, Force motor and SML Isuzu have shown an overall increase in $\mathrm{P} / \mathrm{E}$ ratio over the 5 years. Every company has shown wide fluctuations in ROE by reflecting ups and downs in the graph. In case of SML Isuzu, the graph has shown a sudden rise in $\mathrm{P} / \mathrm{E}$ ratio in the last FY. It may work as a positive indicator for the investors.

3. Dividend payout ratio: It refers to the portion of total net income of a company decided by the management to be paid to stockholders of that company. DPR is calculated by dividing dividend paid to stockholder from net income available with the company.

\begin{tabular}{|l|l|l|l|l|l|}
\hline \multicolumn{7}{|c|}{ Table V. Price to Earnings ratio of five companies (2013-2018) } \\
\hline Years & $\begin{array}{l}\text { Maruti } \\
\text { Suzuki }\end{array}$ & $\begin{array}{l}\text { Mahindra \& } \\
\text { Mahindra }\end{array}$ & Tata motors & Force Motor & SML Isuzu \\
\hline $2013-14$ & 12.70 & 20.70 & 4.63 & 5.07 & 24.94 \\
\hline $2014-15$ & 19.83 & 26.99 & 0.00 & 6.48 & 23.50 \\
\hline $2015-16$ & 13.74 & 24.60 & 0.00 & 7.33 & 22.62 \\
\hline $2016-17$ & 14.07 & 20.92 & 0.97 & 0.00 & 18.37 \\
\hline $2017-18$ & 28.75 & 11.29 & 0.00 & 10.78 & 136.25 \\
\hline
\end{tabular}

Implication: - Higher DPR reflects higher portion of dividend out of the earning which makes the shareholders happy if they want regular income from their investment. There are some investors who want capital appreciation from their investment. That kind of investor hardly gets affected from fall in DPR. As per the table given above, it is shown that all the five companies have different DPR affecting their shareholders in different way. In many years, Tata has not even declared dividend and retain all of the earning for its growth prospect. This is why its DPR is 0.00 .

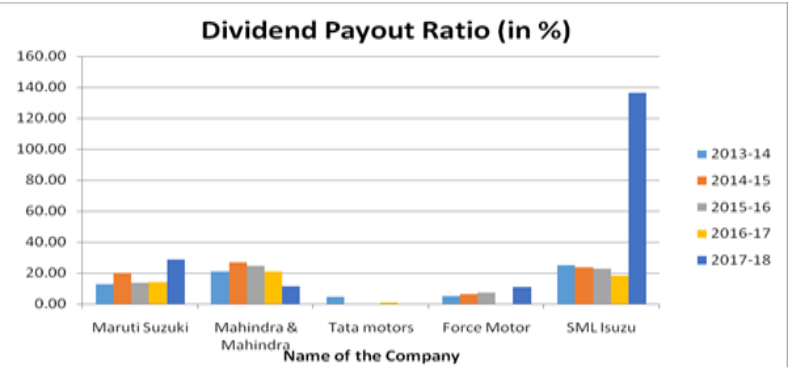

Fig X. Graphical representation of Dividend Payout ratio of five companies (2013-2018) 
In the above graph, name of the companies representing industry as a whole is shown on $\mathrm{X}$ axis and DPR ratio of all the companies from FY 2013-14 to FY 2017-18 is shown on $Y$ axis. It helps in understanding the fluctuation and changing trend of DPR ratio over the years. Maruti, Force motor and SML Isuzu have shown an overall increase in DPR ratio over the 5 years. Maruti Suzuki has shown highest DPR in FY 2017-18 from the initial DPR of $12.7 \%$ in FY 2013-14. There is an outlier of 136.65 in case of SML Isuzu in the last year. This means company wants to pay to its shareholders more than what it earns. In FY 2015, 2016 and 2018, Tata has not declared dividend due to which graph remains at zero.

4. Book value: Book value refers to the total value of a company's assets after subtracting all the outstanding liabilities with company. Book value is a good measure for the valuation of stock by the investor.

\begin{tabular}{|l|l|l|l|l|l|}
\hline \multicolumn{7}{|c|}{ Table VI. Book value in crore Rs. of five companies (2013-2018) } \\
\hline Years & $\begin{array}{l}\text { Maruti } \\
\text { Suzuki }\end{array}$ & $\begin{array}{l}\text { Mahindra \& in crore Rs. ) } \\
\text { Mahindra }\end{array}$ & Tata motors & $\begin{array}{l}\text { Force } \\
\text { Motor }\end{array}$ & SML Isuzu \\
\hline $2013-14$ & 712.21 & 272.46 & 205.04 & 932.53 & 191.00 \\
\hline $2014-15$ & 805.69 & 309.85 & 176.06 & 1001.67 & 209.31 \\
\hline $2015-16$ & 1014.25 & 361.03 & 233.77 & 1125.95 & 235.03 \\
\hline $2016-17$ & 1228.16 & 431.26 & 172.30 & 1266.40 & 279.03 \\
\hline $2017-18$ & 1409.78 & 243.68 & 282.54 & 1367.80 & 275.06 \\
\hline \multicolumn{7}{|c|}{ Source: Money control } \\
\hline
\end{tabular}

As the table suggest, book value of all the companies have increased from FY 2013-14 to FY 2017-18 except for Mahindra \& Mahindra. Though the book value has decreased but still has positive value till FY 2016-17.

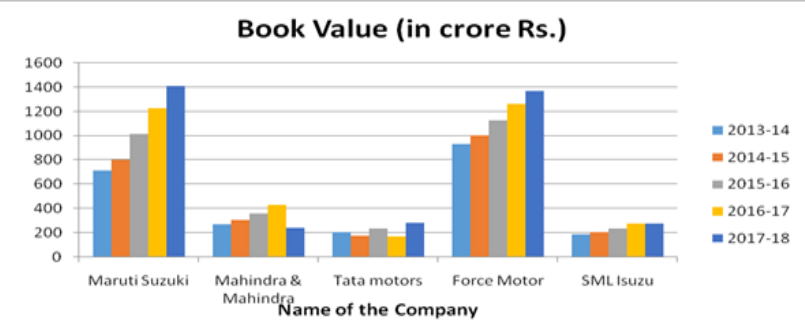

Fig XI. Graphical representation of book value in lakh Rs. of five companies (2013-2018)

In the above graph, name of the companies representing industry as a whole is shown on $\mathrm{X}$ axis and Book value of all the companies from FY 2013-14 to FY 2017-18 is shown on $\mathrm{Y}$ axis. It helps in understanding the fluctuation and changing trend of Book value over the years. Except Mahindra \& Mahindra, all the companies has shown an overall increase in their book value from FY 2013-14 to FY 2017-18. M\&M has shown increasing trend till 2016-17

Valuation of Share: The intrinsic value will be compared with their market value for the decision making.

$\rightarrow \quad$ If the intrinsic value is higher than the market value, the stock is undervalued and therefore, it is recommended to buy that stock. (Intrinsic Value > Market Value).

$\rightarrow \quad$ If the intrinsic value is lower than the market value, it means the stock is overvalued and therefore, it is recommended to sell that stock. This is so because of the strong possibility that the value of share will decrease in future. (Intrinsic Value < Market Value).

\begin{tabular}{|c|c|c|c|c|c|}
\hline \multicolumn{6}{|c|}{ Table VII. Comparison of ratios of all five companies } \\
\hline RATIO & $\begin{array}{l}\text { Maruti } \\
\text { Suzuki }\end{array}$ & $\begin{array}{l}\text { Mahindra \& } \\
\text { Mahindra }\end{array}$ & Tata motors & \begin{tabular}{|l|} 
Force \\
Motor \\
\end{tabular} & SML Isuzu \\
\hline $\begin{array}{l}\text { Average } \\
\text { (total DPS } / \text { no. of years }\end{array}$ & 0.17818 & 0.209 & 0.0112 & 0.05932 & 0.45136 \\
\hline $\begin{array}{l}\text { Average Retention Ratio } \\
\text { (1-DPR) }\end{array}$ & 0.82182 & 0.791 & 0.9888 & 0.94068 & 0.54864 \\
\hline $\begin{array}{ll}\begin{array}{l}\text { Average } \\
\text { (ROE/no. of years) }\end{array} & \text { ROE } \\
\end{array}$ & 0.17126 & 0.15686 & 0.16618 & 0.0902 & 0.1025 \\
\hline $\begin{array}{l}\text { Growth in Equity } \\
\text { (Average Retention Ratio* } \\
\text { Avg. ROE) }\end{array}$ & 0.14074489 & 0.12407626 & 0.164318784 & 0.08484934 & 0.0562356 \\
\hline $\begin{array}{l}\text { Normalised Average P/E } \\
\text { Ratio ( sum of all P/E } \\
\text { Ratio/ No. of years) }\end{array}$ & 27.126 & 21.322 & 11.172 & 20.684 & 114.508 \\
\hline $\begin{array}{l}\text { Projected } \\
\text { (Current EPS } \\
\text { Growth in Equity) }\end{array}$ & 297.597528 & 39.38763215 & 30.80787502 & 121.199368 & 6.20010297 \\
\hline $\begin{array}{l}\text { Intrinsic } \\
\text { (Projected EPS } \\
\text { Normalized Avg. Ratio) }\end{array}$ & 8072.63054 & 839.8230927 & 344.1855798 & 2506.88772 & 709.961391 \\
\hline $\begin{array}{l}\text { Market Value } \\
\text { (as on } 28 / 3 / 2018 \text { ) }\end{array}$ & 8861.1 & 738.9 & 326.85 & 2733 & 768.6 \\
\hline
\end{tabular}

The stock of Maruti is overvalued as intrinsic value (8072.63) is smaller than the market value (8861.10). Therefore, stock of Maruti should be sold.

- The stock of Mahindra \& Mahindra is undervalued as intrinsic value (839.82) is greater than the market value (738.9). Therefore, stock of Mahindra \& Mahindra should be purchased.

The stock of TATA Motors is undervalued as intrinsic value (344.185) is greater than the market value (326.85). Therefore, stock of Tata motors should be purchased.

- The stock of Force motors is overvalued as intrinsic value (2506.88) is smaller than the market value (2733). Therefore, stock of Force Motor should be sold.

The stock of SML Isuzu is overvalued as intrinsic value (709.96) is smaller than the market value (768.6). Therefore, stock of SML Isuzu should be sold.

\section{SUGGESTIONS}

Company analysis helps in finding out intrinsic value of the share through ratio analysis which can then be compared with the actual value of the stock in order to decide on where to invest. It is made clear that the stock of Maruti suzuki, Force motor and SML ISUZU are overvalued and hence should be sold quickly whereas the stock of Mahindra $\&$ Mahindra and TATA motors are undervalued and hence should be bought.

\begin{tabular}{|l|l|l|l|l|}
\hline COMPANY & $\begin{array}{l}\text { Intrinsic } \\
\text { value }\end{array}$ & $\begin{array}{l}\text { Market } \\
\text { Value }\end{array}$ & Outcome & Judgment \\
\hline $\begin{array}{l}\text { Maruti } \\
\text { Suzuki }\end{array}$ & 8072.631 & 8861.1 & $\begin{array}{l}\text { Intrinsic Value }<\text { Market } \\
\text { Value }\end{array}$ & $\begin{array}{l}\text { Overvalued stock } \\
\text { hence sold }\end{array}$ \\
\hline $\begin{array}{l}\text { Mahindra \& } \\
\text { Mahindra }\end{array}$ & 839.8231 & 738.9 & $\begin{array}{l}\text { Intrinsic Value }>\text { Market } \\
\text { Value }\end{array}$ & $\begin{array}{l}\text { Undervalued stock } \\
\text { hence purchased }\end{array}$ \\
\hline $\begin{array}{l}\text { Tata } \\
\text { motors }\end{array}$ & 344.1856 & 326.85 & $\begin{array}{l}\text { Intrinsic Value }>\text { Market } \\
\text { Value }\end{array}$ & $\begin{array}{l}\text { Undervalued stock } \\
\text { hence purchased }\end{array}$ \\
\hline $\begin{array}{l}\text { Force } \\
\text { Motor }\end{array}$ & 2506.888 & 2733 & $\begin{array}{l}\text { Intrinsic Value < Market } \\
\text { Value }\end{array}$ & $\begin{array}{l}\text { Overvalued stock } \\
\text { hence sold stock }\end{array}$ \\
\hline SML Isuzu & 709.9614 & 768.6 & $\begin{array}{l}\text { Intrinsic Value }<\text { Market } \\
\text { Value }\end{array}$ & $\begin{array}{l}\text { Overvalued stock } \\
\text { hence sold }\end{array}$ \\
\hline
\end{tabular}




\section{CONCLUSION}

From the above analysis, it can be said that all the factors under E-I-C framework are showing positive indication to the investor who is thinking to invest for long term. One major reason behind such opportunity is government policies and initiatives. Government of India took several initiatives to boost automotive industry in coming years so as to provide Indian economy with growth and development opportunity. Further, industry analysis is performed to provide investors with all the positive clues of investing in the upcoming trend of automobile industry. Being an important part of fundamental analysis, company analysis is also performed on selected 5 automotive companies among the majors. The result come out to be positive in case of Mahindra \& Mahindra and Tata Motors as their intrinsic value is more than their market value and negative in case of Maruti Suzuki, Force Motors and SML Isuzu as their intrinsic value is less than their market value. On these bases, an investor can take its buy-sell decision related to different security of automotive companies.

\section{REFERENCES}

1. Suresh, A. S. (2013). A study on fundamental and technical analysis. International Journal of Marketing, Financial Services \& Management Research, 6, 44-59.

2. Chauhan, A. A. (2014). A study on fundamental analysis of Indian automobile industry with reference to the selected companies. International Journal of Scientific Research, 3, 254-255.

3. Silpa, K. S., Mol, A., \& Ambily, A. S. (2017). A study on fundamental analysis of selected IT companies listed at NSE. Journal of Advanced Research in Dynamical and Control System.

4. Christie, P., \& Isidore, R. (2018). Fundamental analysis versus technical analysis-A comparative review. International Journal of Recent Scientific Research, 9 (1(B), 23009-23013.

5. Tripathi, V. (2015). Security Analysis \& Portfolio Management. New Delhi: Taxmann Publications.

6. Baresa, S., Bogdan, S., \& Ivanovic, Z. (2013). Strategy of stock valuation by fundamental analysis. UTMS Journal of Economics , 4 (1), 45-51.

7. Bettman, Jenni L., Sault Stephen J., \& Schultz, Emma L. (2009). Fundamental and Technical Analysis Substitutes or complements. AFAANZ Journal of Accounting and Finance.

8. Websites:

9. https://www.rediff.com

10. https://www.statista.com

11. https://economictimes.indiatimes.com

12. https://www.ceicdata.com/en

13. https://www.ibef.org

14. https://www.rbi.org.in/

15. https://www.equitymaster.com/ 